\title{
Pemberdayaan Spiritual Masyarakat Suku Sakai di Kabupaten Bengkalis
}

\author{
Rudi Haryanto \\ Sekolah Tinggi Agama Islam Hubbulwathan Duri \\ (E-mail: rudiharyanto934@gmail.com)
}

\begin{abstract}
The Sakai tribe is one of the stranded tribes in Riau Province. According to Sakai's belief system ritual activities still believe that animism is an expression of the relationship between human nature that can be seen invisible to the unseen world. They are from the beginning of the coming of Islamic still believe that there is a universe other than humans and the environment or its ecosystem. Nature is called the supernatural. This supernatural realm in animism is called his creature with jokes. Occasionally this supernatural. Sakai is worshipe for various tribes in the period of animism, such as treating illness, decreasing rain, giving fortune, giving offspring, and others.
\end{abstract}

Keywords: Empowermen, Spritual, Sakai.

Abstrak: Suku Sakai adalah salah satu suku yang ada di Provinsi Riau. Menurut sistem kepercayaan Sakai, kegiatan ritual masih percaya bahwa animisme adalah ekspresi dari hubungan antara sifat alamiah manusia dengan sesuatu yang tidak dapat dilihat oleh dunia. Suku Sakai dari awal kedatangan Islam masih percaya bahwa ada alam semesta selain manusia dan lingkungan atau ekosistemnya. Alam disebut supernatural. Alam supranatural dalam animisme ini disebut dengan dongeng. Supernatural masyarakat Sakai ini adalah ibadah bagi berbagai suku pada periode animisme, seperti mengobati penyakit, menahan hujan, mendatangkan rezeki, memberi keturunan, dan lain-lain.

Kata kunci: Pemberdayaan, Spritual, Sakai. 
188 Rudi Haryanto, Pemberdayaan Spiritual Masyarakat Suku Sakai di Kabupaten Bengkalis Jurnal At-Taghyir : Jurnal Dakwah dan Pengembangan Masyarakat Desa Volume 1 Nomor 2 Juni 2019, h. 187-206

\section{A. Pendahuluan}

Provinsi Riau merupakan salah satu provinsi yang terdapat di gugusan pulau Sumatera Indonesia Provinsi Riau dikenal sebagai salah satu provinsi terkaya di Indonesia karena memiliki sumber daya alam yang melimpah seperti minyak bumi dan hasil hutannya. Selain kaya akan sumber daya alam dan hasil hutan, Provinsi Riau juga kaya akan budaya dan tradisi baik lisan maupun tulisan. Provinsi Riau merupakan pusat kebudayaan dan tradisi Melayu. Anggapan tersebut didukung oleh fakta bahwa di kawasan ini sampai sekarang masih ada sejumlah suku asli atau yang lebih terkenal dengan sebutan suku terasing, yaitu, suku Sakai,suku Talangmamak, suku Kubu, suku Hutan, dan suku Petalangan yang mendiami daratan di Riau. Kemudian ada suku Laut atau suku Akit yang mendiami kawasan Kepulauan Riau. ${ }^{1}$

Dalam kehidupan masyarakat. suku-suku asli, masyarakat adat dan masyarakat beraja-raja, wujud kebudayaan dan tradisi Melayu masih dipelihara dan menjadi patokan kehidupan sosial. Dalam kehidupan masyarakat suku-suku asli yang ada di Riau (seperti suku Sakai, suku Sakai, suku Talangmamak, suku Kubu, suku Hutan, suku Petalangan dan suku Laut Atau. Suku Akit ) terkesan sangat tradisional, karena mereka memegang teguh adat, budaya dan tradisinya. Suku Sakai adalah salah satu suku terasing di kawasan Provinsi Riau.

Selain suku lainnya yaitu Sakai, Talangmamak, Kubu, Orang Hutan, dan suku Laut atau suku Akit. Masyarakat suku Sakai merupakan salah satu suku asli yang tinggal jauh di pedalaman Sungai Rokan. Masyarakat ini sulit dijangkau dan terisolasi secara sosial. Mereka hidup dari hasil pertanian ladang berpindah-pindah, perikanan, dan meramu. Sebagai suku terpencil di Provinsi Riau, Suku Sakai memiliki aturanaturan yang bisa menjamin kelestarian hutan dan sungai. Bila aturan-aturan yang diberlakukan Suku Sakai ini juga dijalankan suku-suku lain yang ada di Provinsi Riau maka permasalahan kerusakan hutan dan sungai bisa diminimalisir.

Menurut sistem kepercayaan suku Sakai, kegiatan ritual masih mempercayai animis merupakan ekspresi dari hubungan antara alam manusia yang dapat dilihat

${ }^{1}$.Melayu, Riau, Riau, \& Ketemanggungan, 2014). 
189 Rudi Haryanto, Pemberdayaan Spiritual Masyarakat Suku Sakai di Kabupaten Bengkalis Jurnal At-Taghyir : Jurnal Dakwah dan Pengembangan Masyarakat Desa

Volume 1 Nomor 2 Juni 2019, h. 187-206

secara kasat mata dengan alam ghaib. Mereka sejak awal sampai datangnya Islam pun tetap mempercayai bahwa ada alam lain selain manusia dan lingkungan atau ekosistemnya. Alam itu disebut dengan alam gaib. Alam gaib ini pada masa-masa animisme disebut makhluknya denga jembalang-jembalang. Adakalanya makhluk gaib ini dipuja untuk berbagai keperluan suku Sakai di masa animism, seperti mengobati penyakit, menurunkan hujan, memberikan rejeki, memberikan keturunan, dan lainlainnya. ${ }^{2}$

Namun setelah datangnya Islam, unsur animisme itu diubah berdasarkan konsepkonsep Islam. Ajaran Islam selain alam manusia memang dikenal juga dengan alam ghaib yang dihuni oleh para jin. Di antara jin itu ada yang beragama Islam dan ada pula yang beragama lainnya.

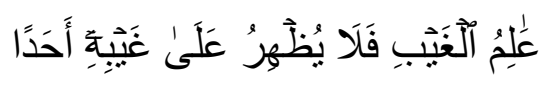

"(Dia adalah Tuhan) Yang Mengetahui yang ghaib, maka Dia tidak memperlihatkan kepada seorangpun tentang yang ghaib itu.",3 (Q.S. Al-Jin:26)

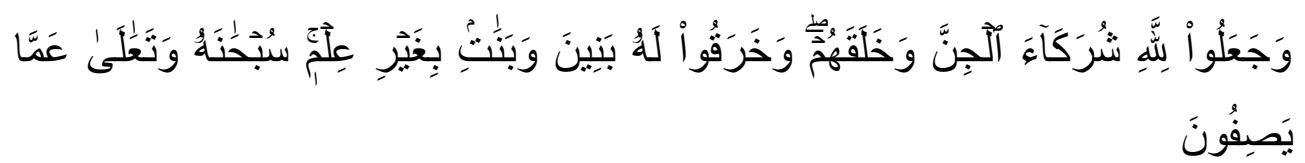

"Dan mereka (orang-orang musyrik) menjadikan jin itu sekutu bagi Allah, padahal Allah-lah yang menciptakan jin-jin itu, dan mereka membohong (dengan mengatakan): "Bahwasanya Allah mempunyai anak laki-laki dan perempuan", tanpa (berdasar) ilmu pengetahuan. Maha Suci Allah dan Maha Tinggi dari sifat-sifat yang mereka berikan." (Al-an'am:100)

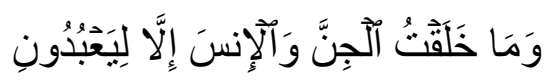

"Dan aku tidak menciptakan jin dan manusia melainkan supaya mereka mengabdi kepada-Ku." ${ }^{, 5}$ (Adzariyat:56)

Ayat-ayat al-Quran di atas tergambar dengan jelas bahwa Allah yang mengetahui tentang yan gaib-gaib itu. Adapun diciptakannya jin dan manusia oleh

\footnotetext{
${ }^{2}$ Melayu, Tanah, Didaerah Riau, Melayu Riau, and Adat Ketemanggungan. 2014. "Pemetaan Rumah Tradisional Melayu Riau" 1 (2): 1-19.

${ }^{3}$ Departemen Agama RI, Al-Qur'an Tajwid dan Terjemah, (Bandung: Diponegoro, 2010), h. 573.

${ }^{4}$ Ibid., h. 140

${ }^{5}$ Ibid., h. 523
} 
190 Rudi Haryanto, Pemberdayaan Spiritual Masyarakat Suku Sakai di Kabupaten Bengkalis Jurnal At-Taghyir : Jurnal Dakwah dan Pengembangan Masyarakat Desa Volume 1 Nomor 2 Juni 2019, h. 187-206

Allah adalah untuk mengabdi kepada Allah. Bahwa jin itu ada yang sesat dan menyesatkan dan ada pula sebahagiannya yang beriman kepada Allah. Menurut peneliti hal ini pula yang terjadi di kalangan suku Sakai, baik pada masa animisme dan kemudian bertransformasi ke masa Islam. Setelah masyarakat suku Sakai memeluk Islam pun kepercayaan terhadap makhluk-makhluk halus ini terus berlanjut, namun berubah konsep dan pandangan. Kalau dalam masa animism, makhluk halus ini dipandang memiliki kekuasaan dan derajat yang lebih tinggi dari manusia, maka setelah Islam datang, makhluk-makhluk halus in dipandang sebagai jin. Berdasarkan hal demikian, maka perlu adanya kajian secara konfrensif tentang pemberdayaan spiritual masyarakat Suku Sakai sesuai denga ajaran Islam.

\section{B. Landasan Teorits}

1. Pengertian Pemberdayaan

Pemberdayaan berasal dar kata“daya”yang mendapat awalan ber- menjadi kata"berdaya" artinya memiliki atau mempunyai daya. Daya artinya kekuatan, berdaya memiliki arti kekuatan. Kata "berdaya" apabila diberi awalan pe-dengan mendapat sisipan -m- dan akhiran -an manjadi "pemberdayaan" artinya membuat sesuatu menjadi berdaya.atau mempunyai.kekuatan. ${ }^{6}$ Kata“"pemberdayaan"adalah terjemahan dari bahasa Inggris"Empowerment", pemeberdayaan.berasal dari kata dasar"power" yang berarti kekuatan berbuat, mencapai, melakukan atau memungkinkan. Awalan "em" pemberdayaan dapat berarti kekuatan dalam diri manusia, suatu sumber kreativitas. Secara konseptual pemeberdayaan (emperworment) berasal dari kata power (kekuasaan atau keberdayaan). ${ }^{7}$

Pemberdayaan menunjuk pada masyarakat yang lemah sehingga mereka memiliki kekuatan atau kemampuan dalam:

a. Memenuhi kebutuhan dasarnya sehingga mereka memiliki kebebasan (freedom), dalam arti bukan saja bebas mengemukakan pendapat, melainkan bebas dari kelaparan, bebas dari kebodohan, bebas dari kesakitan;

\footnotetext{
${ }^{6}$ Rosmedi Dan Riza Risyanti, Pemberdayaan Masyarakat, (Sumedang: Alqaprit Jatinegoro, 2006), hlm. 1

7 Edi Sugarto, Membangun Masyarakat Memberdayakan Rakayat Kajian StrategisPembangunan Kesejahteraan Sosial Dan Pekerja Sosial,(Bandung: PT Ravika Adimatama 2005), Cet Ke-1, hlm. 57
} 
191 Rudi Haryanto, Pemberdayaan Spiritual Masyarakat Suku Sakai di Kabupaten Bengkalis Jurnal At-Taghyir : Jurnal Dakwah dan Pengembangan Masyarakat Desa

Volume 1 Nomor 2 Juni 2019, h. 187-206

b. Menjangkau sumber-sumber produktif yang memungkinkan mereka dapat meningkatkan pendapatannya dan memperoleh. barang-barang dan jasa- jasa yang mereka perlukan;

c. Berpartisipasi dalam proses pembangunan dan keputusan-keputusan yang mempengaruhi mereka. ${ }^{8}$

2. Pemberdayaan menurut Islam

Islam memandang suatu pemberdayaan atas masyarakat madani sebagai suatu hal yang penting sehingga pemberdayaan dalam pandangan Islam akan memiliki pendekatan-pendekatan yang holistik dan strategis. Menurut agus Ahmad Syafiei, pemberdayaan atau empowerment dapat diartikan sebagai penganut, dan secara teknis istilah pemberdayaan dapat disamakan dengan istilah pengembangan. ${ }^{9}$ Menurut Agus Efendi sebagaimana dikutip oleh Nanih Machendrawaty dan Agus Ahmad Safei dalam bukunya Pengembangan Masyarakat Islam, mencoba menawarkan tiga kompleks pemberdayaan yang mendesak.

Pertama, pemberdayaan pada matra ruhaniah. Pemberdayaan ini diperlukan karena degradasi moral masyarakat Islam saat ini sangatlah memprihatinkan. Kepribadian umat Islam terutama generasi mudanya begitu mudah terkooptasi oleh budaya negatif " Barat" yang merupakan antitesa dari nilai-nilai Islam dan tidak dapat memilahnya. Keadan ini masih diperparah oleh gagalnya pendidikan agama di hampir semua pendidikan. Karenanya, umat Islam harus berjuang keras untuk melahirkan disain kurikulum pendidikan yang terfokuskan ke pemberdayaan ruhaniah.

Kedua, pemberdayaan intelektual. Saat ini dapat disaksikan betapa umat Islam yang ada di Indonesia sudah terlalu jauh tertinggal dalam kemajuan dan penguasaan IPTEK. Keadaan ini juga diperparah dengan orientasi lembaga pendidikan yang ada mulai dari tingkat TK sampai Perguruan Tinggi lebih banyak berorientasi pada bisnis semata, lembaga pendidikan dijadikan arena bisnis yang subur. Untuk itu diperlukan berbagai upaya pemberdayaan intelektual sebagai sebuah perjuangan

\footnotetext{
${ }^{8}$ Ibid, hlm. 58

9 Agus Ahmad Syarfi; ${ }^{e}$ I, Menejemen Masyarakat Islam, (Bandung: Gerbang Masyarakat Baru), hlm. 70
} 
192 Rudi Haryanto, Pemberdayaan Spiritual Masyarakat Suku Sakai di Kabupaten Bengkalis Jurnal At-Taghyir : Jurnal Dakwah dan Pengembangan Masyarakat Desa Volume 1 Nomor 2 Juni 2019, h. 187-206

besar dari pengembalian orientasi pendidikan pada pengembangan intelektual an sich.

Ketiga, pemberdayaan ekonomi, harus diakui bahwa kemiskinan dan ketertinggalan menjadi demikian identik dengan mayoritas umat Islam, khususnya di Indonesia. Untuk memecahkannya, tentunya ada dalam masyarakat sendiri, mulai dari sistem ekonomi yang diterapkan oleh pemerintah, keberpihakan pemerintahan dalam mengambil kebijakan ekonomi dan kemauan serta kemampuan masyarakat sendiri. Karenanya, diperlukan sebuah strategi dan kebijakan untuk keluar dari himpitan ketertinggalan dan ketimpangan ekonomi tersebut. ${ }^{10}$

3. Tujuan Pemberdayaan

Tujuan utama pemberdayaaan adalah memperkuat kekuasaaan masyarakat khususnya kelompok lemah yang memiliki ketidakberdayaan, baik karena kondisi internal (misalnya presepsi mereka sendiri), maupun karena kondisi eksternal (misalnya ditindas oleh struktur sosial yang tidak adil) ${ }^{11}$. Ada beberapa kelompok yang dapat dikategorikan sebagai kelompok lemah atau tidak berdaya meliputi:

a. Kelompok lemah secara stuktural, naik lemah secara kelas, gender, maupun etnis.

b. Kelompok lemah khusus, seperti manula, anak-anak, dan remaja penyandang cacat, gay dan lesbian, masyarakat terasing.

c. Kelompok lemah secara personal, yakni mereka yang mengalami masalah pribadi atau keluarga. ${ }^{12}$

4. Tahapan pemberdayaan

Menurut Isbandi Rukminto Adi, pemberdayaan masyarakat memiliki 7 (tujuh) terhadap pemberdayaan, yaitu sebagai berikut:

a. Tahap Persiapan: pada tahapan ini ada dua tahapan yang harus dikerjakan, yaitu: pertama, penyimpanan petugas, yaitu tenaga pemberdayaan masyarakat yang bisa dilakukan oleh community woker, dan kedua penyiapan lapangan yang pada dasarnya diusahakan dilakukan secara non-direktif.

\footnotetext{
${ }^{10}$ Nanih Machendrawaty, Pengembangan Masyarakat Islam, (Bandung: Remaja Rosdakarya, 2001), hlm. 31-50

${ }^{11}$ Soerjono Soekanto, Sosial Suatu Pengantar, (Jakarta, Rajawalipress, 1987), hlm. 75

${ }^{12}$ Edi Sueharto Op. Cit, , hlm. 60
} 
193 Rudi Haryanto, Pemberdayaan Spiritual Masyarakat Suku Sakai di Kabupaten Bengkalis Jurnal At-Taghyir : Jurnal Dakwah dan Pengembangan Masyarakat Desa

Volume 1 Nomor 2 Juni 2019, h. 187-206

b. Tahapan pengkajian (assessment): pada tahapan ini yaitu proses pengkajian dapat dilakukan secara individual melalui kelompok- kelompok dalam masyarakat. Dalam hal ini petugas harus berusaha mengidentifikasi masalah kebutuhan yang dirasakan (feel needs) dan juga sumberdaya yang dimiki klain.

c. Tahap perencanaan alternatif program atau kegiatan: pada tahapan ini petugas sebagai agen perubahan (exchange agent) secara partisipatif mencoba melibatkan warga untuk berfikit tentang masalah yang mereka hadapi dan bagaimana cara mengatasinya. Dalam konteks ini masyarakat diharapkan dapat memikirkan beberapa alternatif program dan kegiatan yang dapat dilakukan.

d. Tahap pemfomalisasi rencanaaksi: pada tahapan ini agen perubahan membantu masing-masing kelompok untuk merumuskan dan menentukan program dan kegiatan apa yang mereka akan lakukan untuk mengatasi permasalahan yang ada. Disamping itu juga petugas membantu untuk memfomalisasikan gagasan mereka kedalam bentuk tertulis, terutama bila ada kaitannya dengan pembuatan proposal kepada penyandang dana.

e. Tahap pelaksanaan (implementasi) program atau kegiatan: dalam upaya pelaksanaan program pemberdayaan masyarakat peren masyarakat sebagai kader diharapkan dapat menjaga keberlangsungan program yang telah dikembangkan. Kerjasama antar petugas dan masyarakat merupakan hal penting dalam tahapan ini karena terkadang sesuatu yang sudah direncanakan dengan baik melenceng saat dilapangan.

f. Tahap evaluasi: evaluasi sebagai proses pengawasan dari warga dan petugas program pemberdayaan masyarakat yang sedang berjalan sebaiknya dilakukan dengan melibatkan warga. Dengan keterlibatan warga tersebut diharpakan dalam jangka waktu pendek biasanya membentuk suatu sistem komunitas untuk pengewasan secara internal dan untuk jangka panjang dapat membangun komunikasi masyarakat yang lebih mendirikan dengan memanfaatkan sumber daya yang ada. 
194 Rudi Haryanto, Pemberdayaan Spiritual Masyarakat Suku Sakai di Kabupaten Bengkalis Jurnal At-Taghyir : Jurnal Dakwah dan Pengembangan Masyarakat Desa Volume 1 Nomor 2 Juni 2019, h. 187-206

g. Tahap terminasi: tahap terminasi merupakan tahapan pemutusan hubungan secara formal dengan komunitas sasaran. Dalam tahap ini diharapkan proyek harus segera berhenti. ${ }^{13}$

5. Pengertian Spritual

Dalam Kamus Besar Bahasa Indonesia, spiritual adalah berhubungan dengan sifat kejiwaan (rohani, batin). Spiritual dapat juga diartikan sebagai nilai-nilai kemanusiaan yang bersifat nonmateri, seperti kebenaran, kebaikan, keindahan, kesucian dan cita. ${ }^{14}$ Menurut Arabi dalam Ruslan spiritualitas adalah pengerahan segenap potensi rohaniah dalam diri manusia yang harus tunduk pada ketentuan syari dalam melihat segala macam bentuk realitas baik dalamdunia empiris maupun dalam dunia kebatinan. ${ }^{15}$ Menurut Al-Qadhi yang dikutip dalam Ruslan mengatakan bahwa spiritualitas adalah tahapan perjalanan batin seorang manusia untuk mencari dunia yang lebih tinggi dengan bantuan riyadah dan berbagai amalan pengekangan diri sehingga perhatiannya tidak berpaling dari Allah, semata-mata untuk mencapai puncak kebahagiaan abadi. Konsep religiositas menurut Islam dapat dijabarkan sebagai berikut:
a. Dimensi ideologis (keyakinan)
b. Dimensi ritualitas (praktik agama)
c. Dimensi eksperiensial (pengalaman
d. Dimensi intelektual
e. Dimensi konsekuensial. ${ }^{16}$

Dimensi-dimensi di atas dalam Islam harus saling berkaitan satu sama lain untuk membentuk religiositas. Religiositas diwujudkan dalam berbagai sisi kehidupan manusia. Dalam Islam, .aktivitas beragama bukan hanya terjadi ketika seseorang melakukan perilaku ritual (beribadah), tetapi juga ketika melakukan aktivitas lain yang didorong oleh kekuatan spiritual. Dalam Islam, seorang Muslim dalam melakukan

\footnotetext{
${ }^{13}$ Ibid, hlm. 63

${ }^{14}$ Departemen Pendidikan Nasional, Kamus Besar Bahasa Indonesia (Jakarta: Gramedia Pustaka Utama, 2000), hlm. 1087.

${ }^{15}$ Ruslan, Menyingkap Rahasia Spiritualitas Ibnu 'Arabi (Makassar: Al-Zikra, Cet.I, 2008), hlm. 16.

${ }^{16}$ Djamaludin Ancok, Psikologi Islam Solusi Islam atas Problem Psikologi (Yogyakarta: Pustaka Pelajar, 1995), hlm. 80-90
} 
195 Rudi Haryanto, Pemberdayaan Spiritual Masyarakat Suku Sakai di Kabupaten Bengkalis Jurnal At-Taghyir : Jurnal Dakwah dan Pengembangan Masyarakat Desa Volume 1 Nomor 2 Juni 2019, h. 187-206

aktivitas apa pun diperintahkan untuk melakukan kegiatan spiritual dengan tujuan beribadah kepada Allah.

Esensi Islam adalah tauhid atau pengesaan Tuhan, tindakan yang menegaskan Allah sebagai yang Esa, pencipta yang mutlak dan transenden, penguasa segala yang ada. Tidak satu pun perintah dalam Islam yang bisa dilepaskan dari tauhid, sehingga kewajiban untuk menyembah Tuhan dengan mematuhi segala perintah-Nya dan menjauhi larangan-Nya. Islam menyuruh untuk beragama (atau berislam) secara menyeluruh. Hal itu telah dijelaskan pada surat Al-Baqarah ayat 208 sebagai berikut:

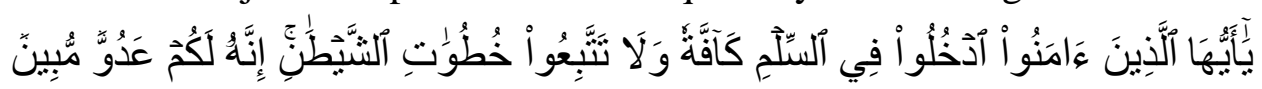

"Hai orang-orang yang beriman, masuklah kamu ke dalam Islam keseluruhan, dan janganlah kamu turut langkah-langkah syaitan. Sesungguhnya syaitan itu musuh yang nyata bagimu." ${ }^{17}$ (Q.S. Albaqarah:208)

Ayat di atas mengandung arti bahwa setiap Muslim, baik dalam berpikir, bersikap maupun bertindak diperintahkan mematuhi syariat Islam. Dalam melakukan aktivitas ekonomi, sosial, politik atau aktivitas apa pun, setiap Muslim diperintahkan untuk melakukanya dengan tujuan beribadah kepada Allah. Sehingga, dapat disimpulkan bahwa tauhid adalah intisari Islam dan suatu tindakan tidak dapat disebut sebagai bernilai Islam tanpa dilandasi oleh kepercayaan kepada Allah.

6. Ciri-ciri Spritual

Agustian mengatakan bahwa di dalam Islam hal-hal yang berhubungan kecakapan spiritual sebagai berikut:
a) Konsistensi (istiqamah)
b) Kerendahan hati (tawadlu)
c) Berusaha dan berserah diri (tawakal)
d) Ketulusan/sincerety (keikhlasan)
e) Totalitas (kaffah)
f) Keseimbangan (tawazun)
g) Integritas \& penyempurnaan (ihsan $)^{18}$

\footnotetext{
${ }^{17}$ Departemen Agama RI, Op.Cit., h.23
} 
196 Rudi Haryanto, Pemberdayaan Spiritual Masyarakat Suku Sakai di Kabupaten Bengkalis Jurnal At-Taghyir : Jurnal Dakwah dan Pengembangan Masyarakat Desa Volume 1 Nomor 2 Juni 2019, h. 187-206

\section{Metode Analisis}

Penelitian ini dilaksanakan selama 5 (lima) bulan yaitu dari bulan Nopember 2018 hingga Maret 2019 dengan lokasi penelitian di Desa Kasumbu Ampai Kecamatan Bathin Solapan Kabupaten Bengkalis, Provinsi Riau. Di mana Suku Sakai banyak bermukim di Kecamatan Bathin Solapan dan saat ini mereka memiliki hutan adat yang terletak di Desa Kesumbo Ampai. Penelitian ini merupakan penelitian kualitatif dengan desain deskriptif, yaitu penelitian yang memberi gambaran secara cermat mengenai individu atau kelompok tertentu tentang keadaan dan gejala yang terjadi. Selanjutnya peneliti akan memberikan gambaran dengan secara cermat tentang fenomena yang terjadi mengenai Suku Sakai di Desa Kesumbo Ampai, Kecamatan Bathin Solapan, Kabupaten Bengkalis, Provinsi Riau. Objek penelitian yang diteliti peneliti keseluruhan sumber daya manusia yang ada di Desa Kesumbo Ampai, Kecamatan Bathin Solapan, Kabupaten Bengkalis, Provinsi Riau dengan jumlah responden 30 orang yang terdiri dari tokoh adat (batin) dan suku asli Sakai, yang menjadi objek penelitian yaitu pengalaman spiritual atau ruhaniah. Teknik pengumpulan data yang dilakukan peneliti adalah melalui observasi, wawancara, dokumentasi yang dilakukan secara cermat dan mendalam, jelas dan spesifik sehingga penelitian ini diharapkan dapat memberikan gambaran seperti apa kearifan lokal masyarakat Sakai dalam pemberdayaan spiritual.

\section{Pembahsan Hasil Penelitian}

\section{Gambaran Umum Wilayah Penelitian}

Lokasi penelitian terletak di Desa Kesumbo Ampai, Kecamatan Bathin Solapan, Kabupaten Bengkalis, Provinsi Riau yang memiliki hutan adat Sakai \pm 500 Ha. Untuk bisa mencapai lokasi Desa Kesumbo Ampai ini perjalanan dengan kendaraan bermotor dari ibu kota propinsi yakni Kota Pekanbaru \pm 3,5 jam. Sementara dari Kota Duri sebagai ibukota Kecamatan Bathin Solapan bisa ditempuh \pm 35 menit. Dari pinggir jalan lintas Duri-Dumai, hutan adat Sakai yang berada di Desa Kesumbo Ampai ini berjarak sekitar 3 kilometer.

Demografi hutan ini terdiri dari lembah-lembah dan dataran rendah yang tidak sejajar sehingga jika dilihat dari pinggir jalan hutan ini seakan-akan lebat di pinggir

${ }^{18}$ Agustian, Ary Ginanjar, Rahasia Sukses Membangun Kecerdasan Emosi dan Spiritual (ESQ), Jilid Pertama, (Arga Wijaya Persada, Jakarta, 2001), hlm. 200. 
197 Rudi Haryanto, Pemberdayaan Spiritual Masyarakat Suku Sakai di Kabupaten Bengkalis Jurnal At-Taghyir : Jurnal Dakwah dan Pengembangan Masyarakat Desa

Volume 1 Nomor 2 Juni 2019, h. 187-206

namun kosong di dalam.Karena cahaya matahari terlihat jelas menembus sela-sela pepohonan. Hal ini dikarenakan kondisi demografi hutan yang berlembah-lembah. Sementara kalau ditelusuri hutan ini sangat padat ditumbuhi berbagai pepohonan alami. Suku Sakai selama ini sering dicirikan sebagai kelompok terasing yang hidup berpindah-pindah di hutan.

Namun seiring dengan berjalannya waktu, alam asri tempat mereka berlindung mulai punah. Kawasan yang tadinya hutan, berkembang menjadi daerah industri perminyakan, usaha kehutanan, perkebunan karet dan kelapa sawit, dan sentra ekonomi. Komposisi masyarakatnya pun menjadi lebih heterogen dengan pendatang baru dan pencari kerja dari berbagai kelompok masyarakat yang ada di Indonesia (Jawa, Minang, Batak, dan sebagainya). Akibatnya, masyarakat Sakai pun mulai kehilangan sumber penghidupan, sementara usaha atau kerja di bidang lain belum biasa mereka jalani dan sebagian besar masyarakat Sakai hidup dari bertani dan berladang.

\section{Budaya Suku Sakai}

Untuk dapat mengetahui dan mengenal lebih jelas kebudayaan suku sakai, kita dapat melihatnya melalui tujuh unsur kebudayaanya, yaitu:

a. Bahasa Suku Sakai

Bahasa Sakai digunakan oleh masyarakat Suku Sakai sebagai alat komunikasi antar etnik dan terkadang juga digunakan dalam berkomunikasi dengan penduduk yang berlainan etnis. Komunikasi dengan penduduk yang berlainan etnis dapat terlaksana karena struktur maupun kosa kata bahasa Sakai memiliki banyak persamaan dengan bahasa Melayu dan Bahasa Minangkabau. Penduduk di Kecamatan Bathin Solapan pada umumnya dapat berbahasa Melayu dan berbahasa Minangkabau. Selain untuk berkomunikasi, banyak kata dalam bahasa Sakai yang digunakan untuk menamai jenis kayu yang ada disekitar lingkungan mereka. Bahasa Sakai ini juga digunakan sebagai bahasa pergaulan dan bahasa budaya dalam kehidupan seharihari masyarakat suku Sakai.

b. Sistem Kekerabatan dan Organisasi Sosial Suku Sakai

Masyarakat Sakai pada masa lalu mempunyai sistem pemerintahan yang mereka sebut Perbatinan yang dipimpin oleh Batin. Orang Sakai menempati 13 anak sungai, 
198 Rudi Haryanto, Pemberdayaan Spiritual Masyarakat Suku Sakai di Kabupaten Bengkalis Jurnal At-Taghyir : Jurnal Dakwah dan Pengembangan Masyarakat Desa Volume 1 Nomor 2 Juni 2019, h. 187-206

permukiman mereka disebut batin. Perbatinan ini terdiri atas Perbatinan Lima dan Perbatinan Delapan. Disebut dengan Perbatinan Lima mereka masing-masing perbatinan mempunyai tanah hak ulayat dan hutan di (1) Minas; (2) Kuala Penaso; (3) Beringin; (4) Belutu; dan (5) Tengganau. Perbatinan Delapan adalah kelompok orang Sakai yang di beri hak untuk membuka hutan oleh Raja Siak Sri Indrapura meliputi wilayah (1) Petani; (2) Sebanga; (3) Air Jamban; (4) Pinggir; (5) Semunai; (6) Sam-Sam; (7) Kandis; (8) Balai Makam.

Sistem kekerabatan Suku Sakai menganut matrilineal yaitu dititik beratkan menurut garis keturunan ibu/perempuan. Yang lebih diutamakan adalah kedudukan anak perempuan dari anak laki-laki. Anak perempuan penerus keturunan ibunya, sedangkan anak laki-laki hanya seolah-olah pemberi bibit keturunan kepada isteri. Dalam budaya Sakai hak perempuan Sakai besar, semua barang milik baik yang bergerak maupun tidak bergerak adalah milik wanita. Kedudukan kepala suku diwariskan dari wanita, dan anak-anak mengikuti ibu, bukan ayah. Karena itu menurut masyarakat Sakai apabila suatu keluarga tidak memiliki anak perempuan, maka seolah-olah hidup tidak berkesinambungan. Namun demikian bukan berarti anak laki-laki tidak berfungsi dalam keluarga. Anak laki-laki membantu orang tua meringankan beban hidup keluarga. Namun menurut Bosniar dalam kehidupan masyarakat Sakai sekarang banyak juga yang memakai hukum Islam dalam lembaga waris mereka, artinya sistem matrilineal digunakan untuk menentukan kerabat tapi dalam pembagian waris mereka sebagian menggunakan hukum Islam.

c. Peralatan Hidup Suku Sakai

Peralatan yang digunakan masyarakat suku Sakai dalam kesehariannya dapat terlihat pada aktivitas berburu dan berladangnya, dalam hal berburu Peralatan yang digunakan oleh suku Sakai adalah parang, panah dan juga memakai jerat sentakserta konjouw. Konjouw adalah tombak yang terbuat dari besi yang dipanaskan, konjouw itu dibekali oleh mantra-mantra hewan. Tidak hanya berburu, orang sakai sangat terkenal dengan mencari ikan dengan menggunakan perahu serta kail tradisional hasil buatan mereka sendiri dan suku Sakai juga senang menangkap udang dan kepiting dengan menggunakan perangkap yang berbentuk kerucut yang terbuat dari anyaman bambu atau rotan. 
199 Rudi Haryanto, Pemberdayaan Spiritual Masyarakat Suku Sakai di Kabupaten Bengkalis Jurnal At-Taghyir : Jurnal Dakwah dan Pengembangan Masyarakat Desa

Volume 1 Nomor 2 Juni 2019, h. 187-206

\section{d. Sistem Mata Pencaharian Hidup Suku Sakai}

Masyarakat suku sakai memiliki banyak bentuk mata pencaharian, hal ini dikarenakan system ekonomi yang dilakukan oleh masyarakat suku sakai di pengaruhi kondisi daerah yang mereka tempati atau yang mereka huni. Oleh karena itu masyarakat suku sakai mempunyai banyak bentuk mata pencarian demi menghidupi keluarganya di antara banyak mata pencarian yang dilakukan masyarakat suku sakai antara lain adalah:

1) Berladang

Dalam kehidupan sosial mereka setiap orang sakai atau setiap keluarga mereka harus mempunyai sebidang tanah atau sebidang ladang. Pada umumnya anakanak laki-laki yang lajang atau yang belum mempunyai istri seharusnya atau wajib sudah mempunyai ladang, setidaknya sedikit bidang ladang. Jika anak bujang dari keluarga suku sakai tersebut tidak mempunyai ladang maka anak bujang ini ikut membantu dan mempunyai bagian ladang sendiri, dari sebuah ketetanggaan ladang bersama dengan kerabat dekat yaitu kakak perempuan ( dalam urut pertama ) atau kakak laki-laki ( yang sudah berkeluarga ). Karena dengan hasil berladang ini lah membuat mereka dapat memenuhi kebutuhan makanan sehari-hari. Ladang merupakan faktor pertama dalam memenuhi kehidupan suku sakai, karena ladang merupakan tempat mereka di hidupkan dari kecil sehingga menjadi dewasa. Rumah-rumah mereka dibangun di atas ladang, serta diladang inilah mereka merasa kehidupan yang dapat membedakan antara hak pribadi dan hak-hak sosial keluarga mereka masing-masing.

2) Berburu dan Mencari Ikan di Sungai

Berburu atau mencari ikan merupakan mata pencaharian asli suku sakai, sedangkan berladang dipengaruhi oleh pada masa kesultanan siak. Pengertian berburu oleh orang sakai bukanlah kegiatan yang membunuh hewan tetapi mereka melakukan dengan menjerat alat buruan mereka yaitu konjouw. Konjouw adalah tombak yang terbuat dari besi yang dipanaskan, konjouw itu dibekali oleh mantra-mantra hewan. Hewan yang mereka sering buru adalah kera, babi hutan, kijang, dan kancil. Hasil tangkapan buruan ini mereka gunakan untuk kebutuhan hidup sehari-hari biasanya mereka jadikan sebagai lauk pauk tidak hanya berburu, orang sakai sangat terkenal dengan mencari ikan. 
200 Rudi Haryanto, Pemberdayaan Spiritual Masyarakat Suku Sakai di Kabupaten Bengkalis Jurnal At-Taghyir : Jurnal Dakwah dan Pengembangan Masyarakat Desa Volume 1 Nomor 2 Juni 2019, h. 187-206

Cara yang mereka lakukan adalah dengan mengail, serta mereka juga senang menangkap udang dengan menggunakan tangguk, suku Sakai mengenal lebih dari 30 jenis ikan. Suku Sakai menangkap ikan dengan menggunakan lukah dan jaring, orangorang sakai pada masa lalunya memasang lukah dari jarring pada sore hari menjelang malam dan pada pagi hari dapat dilihat hasil tangkapannya. Pada biasanya ikan yang mereka tangkap langsung mereka goreng. Jika jumlah tangkapannya relative banyak maka sebagian dari ikan itu untuk dijual kepada orang lain, bahkan suku sakai biasanya membarter ikan tangkapan dengan barang yang mereka perlukan.

\section{e. Sistem Religi Suku Sakai}

Salah satu ciri masyarakat Sakai adalah agama mereka yang bersifat animistik. Meskipun banyak di antara orang Sakai yang telah memeluk Islam, namun mereka tetap memraktekkan agama nenek moyang mereka yang masih diselimuti unsur-unsur animisme, kekuatan magis, dan tentang mahkuk halus. Inti dari agama nenek moyang masyarakat Sakai adalah kepercayaan terhadap keberadaan 'antu', atau mahluk gaib yang ada di sekitar mereka. Masyarakat Sakai menganggap bahwa antu juga memiliki kehidupan layaknya manusia. Mereka bergerombol dan memiliki kawasan pemukiman. Pusat dari pemukiman antu ini menurut orang Sakai berada di tengah-tengah rimba belantara yang belum pernah dijamah manusia. Akan tetapi kepercayaan animisme yang dahulu dianut oleh sebagian besar suku Sakai, kini berganti dengan beberapa agama seperti Islam, atau pun juga Kristen. Sehingga keyakinan terhadap makhluk halus yang sering disebut 'Antu, tidak lagi menyelimuti kehidupan mereka. Hal ini terjadi akibat banyaknya pembukaan hutan untuk perkebunan sawit dan juga pemukiman penduduk baru serta program transmigrasi yang telah mempengaruhi cara pemikiran dan juga pola hidup suku sakai.

\section{Pemberdayaan Spritual Suku Sakai}

Pemberdayaan Spritual Suku Sakai adalah suatu pemberdayaan yang berjalan terus-menerus untuk meningkatkan kemampuan dan kemandirian setiap individu. Hal ini dikarenakan bahwa setiap individu mempunyai potensi dan daya untuk mengembangkan dirinya menjadi lebih baik. Selanjutnya untuk mendapatkan hasil pemberdayaan secara maksimal dilakukan proses penyadaran, pengkapasitasan, pendayaan. 
201 Rudi Haryanto, Pemberdayaan Spiritual Masyarakat Suku Sakai di Kabupaten Bengkalis Jurnal At-Taghyir : Jurnal Dakwah dan Pengembangan Masyarakat Desa Volume 1 Nomor 2 Juni 2019, h. 187-206

a. Penyadaran Masyarakat Suku Sakai

Penyadaran yang diaplikasikan di Suku Sakai secara keseluruhan mempunyai tujuan agar masyarakay menemukan sumberdaya yang ada pada dirinya. Masyarakat yang sadar menjadi semakin tajam mengetahui apa yang sedang terjadi baik di dalam maupun di luar dirinya.

1) Motivasi

Motivasi di Suku Sakai merupakan mendorong masyarakat dan mempengaruhi tingkah laku agar bergerak hatinya untuk bertindak melakukan sesuatu sehingga mencapai hasil atau tujuan tertentu. Berdasarkan hasil observasi motivasi yang dilakukan oleh Suku Sakai dilaksanakan setiap malam jumat. Berdasarkan hasil wawancara dengan Dasuki menjelaskan sebagai berikut: Pembinaan dan motivasi yang dilakukan di Suku Sakai mencakup nilai disiplin beribadah yaitu 1) memotivasi para masyarakat untuk melaksanakan shalat wajib, secara berjamaah 2) Memusatkan perhatian dalam menanamkan dan mengamalkan kalimat tauhid. 3) Memotivasi untuk bersikap jujur, menjaga rahasia, menjaga amanat, menjauhi diri dari sikap hasud, iri hati dan takabur. ${ }^{19}$ Edi Sarwedi menjelaskan tentang kegunaan kegiatan motivasi yang dilakukan oleh Suku Sakai sebagai berikut: Manfaat motivasi yang dilakukan oleh Suku Sakai adalah menciptakan semangat beribadah. Sementara itu, manfaat yang diperoleh karena sudah termotivasi adalah beribadah tepat waktu. Berdasarkan hal demikian maka kegiatan motivasi dan penyadaran yang dilakukan di Suku Sakai sangatlah berguna untuk menciptakan kedisiplinan. Berdasarkan hasil observasi, peneliti menarik kesimpulan bahwa adanya efek motivasi yang dilakukan di Suku Sakai terhadap disiplin masyarakat dalam beribadah tercermin dalam perilaku masyarakat sebagai berikut: 1) Tertib melaksanakan shalat wajib berjamaah 2) Shalat sunnah. 3) Puasa sunat Senin Kamis. Selain itu motivasi tentang kesabaran dan ketekunan juga disampaikan untuk membangkitkan motivasi para masyarakat.

2) Renungan

Renungan merupakan memikirkan sesuatu dengan mendalam. Kegiatan renungan bertujuan untuk menyadari dan memikirkan suatu hal yang terjadi di kehidupan sehari-hari. Kegiatan renungan di Suku Sakai merupakan salah satu kegiatan

\footnotetext{
${ }^{19}$ Dasuki wawancara. 17 Maret 2019, Pukul 15.00 WIB
} 
202 Rudi Haryanto, Pemberdayaan Spiritual Masyarakat Suku Sakai di Kabupaten Bengkalis Jurnal At-Taghyir : Jurnal Dakwah dan Pengembangan Masyarakat Desa

Volume 1 Nomor 2 Juni 2019, h. 187-206

yang dilakukan oleh peneliti. Berdasarkan hasil wawancara dengan Amiruddin menjelaskan sebagai berikut: Pembentukan kepribadian masyarakat Suku Sakai dilakukan melalui kegiatan renungan yang diadakan peneliti."Saya merasakan manfaat yang besar dengan bergabung di kegiatan renungan. Hidup saya menjadi lebih teratur, mempunyai tujuan dalam menjalani kegiatan serta mengetahui akan makna kehidupan yang sebenarnya. Akhirnya saya dapat membentuk diri saya menjadi pribadi yang bisa menyesuaikan diri dengan kondisi apapun, di lingkungan manapun tanpa takut memakai atribut saya sebagai seorang masyarakat. ${ }^{20}$ Berdasarkan hasil wawancara dengan Agushar menjelaskan sebagai berikut: Renungan yang dilakukan oleh peneliti mengenai hati yang bisa selamat dan bisa sakit. Hati yang selamat diartikan sebagai hati yang terbebas dari setiap syahwat, keinginan yang bertentangan dengan perintah Allah. Hati yang mati adalah hati yang tidak mengenal siapa Rabbnya. Hati model ini selalu berjalan bersama hawa nafsu dan kenikmatan duniawi, walaupun itu dibenci dan dimurkai oleh Allah. Baginya yang penting adalah memenuhi keinginan hawa nafsu. Hawa nafsu telah menjadikannya tuli dan buta selain kepada kebatilan. $^{21}$

b. Pengkapasitasan Masyarakat Suku Sakai

Pengkapasitasan masyarakat Suku Sakai bertujuan untuk memampukan masyarakat yang kurang mampu sehingga mereka memiliki keterampilan. Pengkapasitasan yang dilakukan di Suku Sakai dengan cara memberikan pelatihan. Pelatihan di Suku Sakai merupakan persiapan untuk beribadah. Pelatihan tersebut dalam rangka transformasi ilmu untuk dapat disampaikan yang kemudian dan diaplikasikan dalam kehidupan bermasyarakat.

c. Pendayaan Masyarakat Suku Sakai

Ibadah adalah suatu bentuk ketundukan dan ketaatan sebagai dampak dari rasa pengagungan dalam lubuk hati seseorang terhadap yang telah menciptakannya. Secara umum ibadah memiliki arti segala sesuatu yang dilakukan manusia atas dasar patuh terhadap pencipta Nya sebagai jalan untuk mendekatka diri kepada-Nya.

Berdasarkan observasi ibadah yang berada di Suku Sakai bermazhabkan imam Syafi;i. Ha ini terlihat dari sholat subuh dimana para masyarakat menggunakan qunut, dan berzikir bersama-sama. Sedangkan sholat fardu lainnya Suku Sakai membuat

\footnotetext{
${ }^{20}$ Amiruddin, Wawancara, 06 Maret 2019, Pukul. 10.00 WIB

${ }^{21}$ Agushar, wawancara, 26 Januarir 2019, Pukul: 21.05 WIB
} 
203 Rudi Haryanto, Pemberdayaan Spiritual Masyarakat Suku Sakai di Kabupaten Bengkalis Jurnal At-Taghyir : Jurnal Dakwah dan Pengembangan Masyarakat Desa

Volume 1 Nomor 2 Juni 2019, h. 187-206

kebiasaan dengan berjamaahterlihat bahwa sebagian masyarakat sudah berada di mesjid ketika waktu sholat sudah datang, para masyarakat silih beramai-ramai mendatangi masjid sehingga masjid terisi penuh untuk melaksanakan sholat berjamaah.

Berdasarkan hasil wawancara dengan beberapa masyarakat Suku Sakai menjelaskan tentang mamfaat pemberdayaan sholat sebagai berikut: Taqarrûb ilallâh. Pemberdayaan sholat yang berada di Suku Sakai merupakan proses mendekatkan diri kepada Allah SWT. Shalat merupakan sarana dialog antara manusia dengan Tuhannya, sehingga manusia akan merasa dekat dengan Tuhannya yang terlihat dari aspek-aspek shalat, baik hati, ucapan maupun gerakan. ${ }^{22}$ Mencegah dari sifat keji dan munkar. Pemberdayaan sholat mencegah dari sifat keji dan munkar. Hal ini akan tampak dari cerminan akhlak atau perilaku sehari-hari, disamping terhindar dari perbuatan keji, dosa dan kemunkaran dengan memelihara shalat, tentulah hatinya juga suci dan bersih jiwanya. Kesucian hati dan jiwa akan membawa keberuntungan dan kebahagian bagi orang tersebut di dunia dan kebahagian kekal di akhirat. ${ }^{23}$

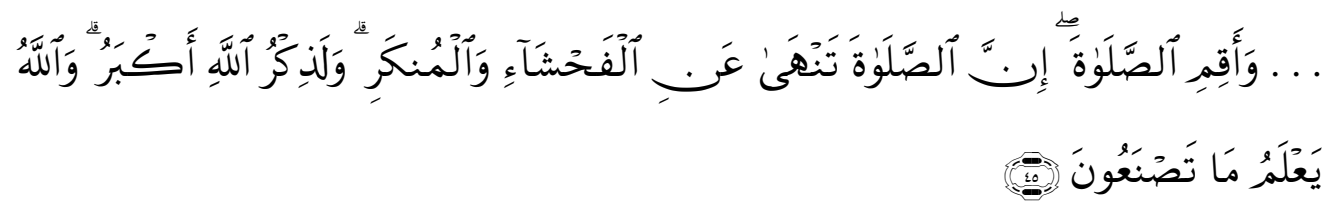

“. . . Sesungguhnya shalat itu mencegah dari (perbuatan-perbuatan) keji dan mungkar. dan Sesungguhnya mengingat Allah (shalat) adalah lebih besar (keutamaannya dari ibadat-ibadat yang lain). dan Allah mengetahui apa yang kamu kerjakan. ${ }^{24}$ (Q.S. alankabut 45)

Shalat menimbulkan jiwa yang tenang. Mengingat Allah SWT hati menjadi tentram dan jiwa menjadi tenang, tidak gelisah, takut atau khawatir, karena orang yang senantiasa mengingat Allah akan melakukan hal-hal yang baik dan ia merasa bahagia dengan kebajikan yang telah diakukan. Mengingat Allah lewat shalat akan membawa keteguhan hati dan sikap optimis serta ketenangan jiwa. Shalat dapat menimbulkan ketenangan hati dan ketentraman batin. ${ }^{25}$ Sifat sabar dalam Islam menempati posisi yang istimewa. Al-Qur'an mengaitkan sifat sabar dengan bermacam-macam sifat mulia. Mengaitkan satu sifat dengan banyak sifat mulia lainnya menunjukkan betapa

\footnotetext{
${ }^{22}$ Anwar (Masyarakat Suku Sakai), wawancara Minggu, 01 Januari 2019, Pukul:09.20 WIB.

${ }^{23}$ Sonnif (Masyarakat Suku Sakai), wawancara, Minggu, 01 Januari 2019, Pukul:09.50 WIB.

${ }^{24}$ Departemen Agama RI, Op.Cit., h. 401

${ }^{25}$ Manab (Masyarakat Suku Sakai), wawancara, Minggu, 01 Januari 2019, Pukul: 10.20 WIB.
} 
204 Rudi Haryanto, Pemberdayaan Spiritual Masyarakat Suku Sakai di Kabupaten Bengkalis Jurnal At-Taghyir : Jurnal Dakwah dan Pengembangan Masyarakat Desa

Volume 1 Nomor 2 Juni 2019, h. 187-206

istimewanya sifat itu, karena sabar merupakan sifat mulia yang istimewa, tentu dengan sendirinya orang-orang yang sabar Juga menempati posisi yang istimewa. Berdasarkan hasil wawancara dengan Johanda menjelaskan tentang banyaknya ayat yang menunjukkan keutamaan sabar sebagai berikut: ${ }^{26}$ Surah Al-Mu'minin ayat 55:

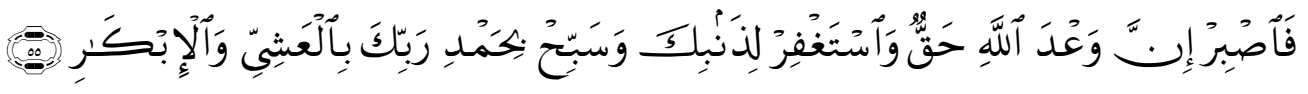

"Maka bersabarlah kamu, karena Sesungguhnya janji Allah itu benar, dan mohonlah ampunan untuk dosamu dan bertasbihlah seraya memuji Tuhanmu pada waktu petang dan pagi." (Q.S. Al-Mu'minin ayat 55)

Surah Al-Ahqaaf ayat 35

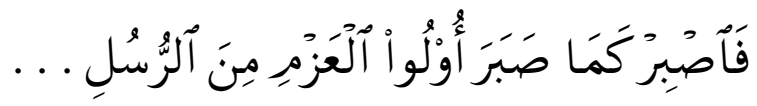

"Maka bersabarlah kamu seperti orang-orang yang mempunyai keteguhan hati dari Rasul-rasul..."27 ( Q.S. Al-Ahqaaf ayat 35).

Selanjutnya hasil wawancara dengan Iskandar menjelaskaan sebagai bahwa: Pemberdayaan sabar di Suku Sakai selalu kami berikan materi agar para masyarakat tidak terlalu mengandalkan kehendaknya sendiri sesuai yang dikehendakinya. 1) Sabar dalam beribadat. Sabar mengerjakan ibadat ialah dengan tekun mengendalikan diri melaksanakan syarat-syarat dan tata-tertib ibadah itu. 2) Sabar ditimpa malapetaka. Sabar ditimpa malapetaka atau musibah ialah teguh hati ketika mendapat cobaan, baik yang berbentuk kemiskinan, maupun berupa kematian, kejatuhan, kecelakaan, diserang penyakit dan lain-lain sebagainya. Kalau malapetaka itu tidak dihadapi dengan kesabaran, maka akan terasa tekanannya terhadap jasmaniah maupun rohaniah. Badan semakin lemah dan lemas, hati semakin kecil. Timbullah kegelisahan, kecemasan, panik dan akhirnya putus-asa. 3) Sabar terhadap maksiat. Sabar terhadap maksiat ini ialah mengendalikan diri supaya jangan melakukan perbuatan maksiat. Tarikan untuk mengerjakan maksiat itu sangat kuat sekali mempengaruhi manusia, sebab senantiasa digoda dan didorong oleh iblis. ${ }^{28}$ Berdasarkan hasil wawancara penulis menarik

\footnotetext{
${ }^{26}$ Johanda (Masyarakat Suku Sakai), wawancara, 04 Januari 2019, Pukul:15.00 WIB

${ }^{27}$ Departemen Agama RI, Op.Cit., h. 506

${ }^{28}$ Iskandar, wawancara, Rabu, 05 Januari 2019, Pukul:10.00 WIB
} 
205 Rudi Haryanto, Pemberdayaan Spiritual Masyarakat Suku Sakai di Kabupaten Bengkalis Jurnal At-Taghyir : Jurnal Dakwah dan Pengembangan Masyarakat Desa

Volume 1 Nomor 2 Juni 2019, h. 187-206

kesimpulan bahwa pemberdayaan kesabaran di Suku Sakai sangat penting dalam menghadapi segala permasalahan hidup yaitu sebagai sikap jiwa yang tangguh dan kuat terhadap berbagai macam terpaan badai kerhidupan dan akhirnya akan mudah mencapai kesuksesan dan kejayaan. Setiap kesuksesan yang dicapai di dunia maupun di akhirat kelak akan selalu berkaitan dengan kesabaran seseorang, Pada dasarnya kehidupan manusia di dunia ini adalah perjalanan jauh menuju Allah Swt.

\section{E. Penutup}

Suku Sakai adalah salah satu suku keturunan Minangkabau yang telah hidup di pedalaman Riau sejak Abad ke 14. Bahasa yang digunakan masyarakat suku sakai adalah bahasa Sakai yang hampir mirip dengan bahasa melayu dan minangakabau, sehingga hal ini memungkinkan mereka untuk berkomunikasi dengan menggunakan bahasa sakai tidak hanya dengan sesama etnisnya, namun juga dengan etnis lainnya yang ada disekitar mereka. Masyarakat suku sakai memiliki banyak sistem mata pencaharian yang hampir seluruhnya dilakukan dengan memanfaatkan sumber daya alam yang ada disekitarnya termasuk berladang, berburu, menangkap ikan dirawa-rawa, dan lain sebagainya. Pemberdayaan spiritual yang dilakukan di suku Sakai terfokus ke ibadah dan kesabaran. Selanjutnya pemberdayaan tersebut mempunyai tahapan yaitu penyadaran, pengkapasitasan dan pendayaan. 
206 Rudi Haryanto, Pemberdayaan Spiritual Masyarakat Suku Sakai di Kabupaten Bengkalis Jurnal At-Taghyir : Jurnal Dakwah dan Pengembangan Masyarakat Desa Volume 1 Nomor 2 Juni 2019, h. 187-206

Daftar Pustaka

Melayu, Tanah, Didaerah Riau, Melayu Riau, and Adat Ketemanggungan. 2014. "Pemetaan Rumah Tradisional Melayu Riau" 1 (2): 1-19.

Departemen Agama RI, Al-Qur'an Tajwid dan Terjemah, Bandung: Diponegoro, 2010.

Rosmedi Dan Riza Risyanti, Pemberdayaan Masyarakat, Sumedang: Alqaprit Jatinegoro, 2006.

Edi Sugarto, Membangun Masyarakat Memberdayakan Rakayat Kajian StrategisPembangunan Kesejahteraan Sosial Dan Pekerja Sosial,(Bandung: PT Ravika Adimatama 2005.

Agus Ahmad Syarfi; ${ }^{\circ}$ I, Menejemen Masyarakat Islam, (Bandung: Gerbang Masyarakat Baru.

Nanih Machendrawaty, Pengembangan Masyarakat Islam, (Bandung: Remaja Rosdakarya, 2001.

Soerjono Soekanto, Sosial Suatu Pengantar, (Jakarta, Rajawalipress, 1987.

Departemen Pendidikan Nasional, Kamus Besar Bahasa Indonesia (Jakarta: Gramedia Pustaka Utama, 2000.

Ruslan, Menyingkap Rahasia Spiritualitas Ibnu 'Arabi (Makassar: Al-Zikra, Cet.I, 2008.

Djamaludin Ancok, Psikologi Islam Solusi Islam atas Problem Psikologi (Yogyakarta: Pustaka Pelajar, 1995.

Agustian, Ary Ginanjar, Rahasia Sukses Membangun Kecerdasan Emosi dan Spiritual (ESQ), Jilid Pertama, Arga Wijaya Persada, Jakarta, 2001.

Iskandar, wawancara, Rabu, 05 Januari 2019, Pukul:10.00 WIB

Manab (Masyarakat Suku Sakai), wawancara, Minggu, 01 Januari 2019, Pukul: 10.20 WIB.

Johanda (Masyarakat Suku Sakai), wawancara, 04 Januari 2019, Pukul:15.00 WIB

Anwar (Masyarakat Suku Sakai), wawancara Minggu, 01 Januari 2019, Pukul:09.20 WIB.

Sonnif (Masyarakat Suku Sakai), wawancara, Minggu, 01 Januari 2019, Pukul:09.50 WIB.

Dasuki wawancara. 17 Maret 2019, Pukul 15.00 WIB

Amiruddin, Wawancara, 06 Maret 2019, Pukul. 10.00 WIB

Agushar, wawancara, 26 Januarir 2019, Pukul: 21.05 WIB 